\title{
The formal independence of regulatory authorities in Turkey
}

\section{İhsan Kulali* and Yavuz Göktaylar}

Bilgi Teknolojileri ve İletişim Kurumu, Yeşilırmak Sok. No. 1606430 Demirtepe, Ankara, Turkey

Fax: +90-312-2947224

Fax: +90-312-2947764

E-mail: ikulali@gmail.com

E-mail: ygoktaylar@gmail.com

*Corresponding author

\begin{abstract}
Turkey has experienced important institutional transformation during the last decades. A substantial part of this transformation is the establishment of independent regulatory authorities. Their independence from political power has attracted debate among the public from time to time. In 2011, massive legal amendments changed the Turkish public administration structure including IRAs. The aim of this paper is to assess effects of these legal amendments on IRAs' independence. To consider effects of those legal amendments on formal independence, a formal independence index is calculated before and after legal amendments for seven IRAs. The results show that formal independence index scores calculated after legal amendments in 2011 are lower than formal independence index scores calculated before those amendments.
\end{abstract}

Keywords: formal independence; independence; independent regulatory authorities; regulation; regulatory state; Turkey.

Reference to this paper should be made as follows: Kulali, İ. and Göktaylar, Y. (2013) 'The formal independence of regulatory authorities in Turkey', Int. J. Management and Network Economics, Vol. 3, No. 1, pp.22-38.

Biographical notes: İhsan Kulalı is a member of the Information and Communication Technologies Board (since 2007), the Head of Tariffs Department at Telecommunications Authority (2003-2007), a Telecommunications Expert at Telecommunications Authority (2001-2003), an Assistant Planning and Planning Expert at State Planning Organization of the Republic of Turkey (1993-2001), and holds PhD in Management at Ankara University (2006), MBA at Leeds University (1999), and BS in Management at METU (1992). He is interested in regulation.

Yavuz Göktaylar is ICT Chief Expert at ICTA (since 2011); ICT Expert at ICTA (2011-2005), an Telecommunications Assistant Expert at Telecommunications Authority (2001-2005); and holds MA in Economics at Boston University (2008); MSc in Science and Technology Policy Studies at METU (2007); and BS in Economics at METU (2000). He is interested in regulation and technology policies. 


\section{Introduction}

In the last three decades, Turkey has experienced important institutional transformation. Especially, 2001 economic crisis has accelerated the institutional change. The Central Bank's independence from the political authorities, liberalisation of electricity, gas, telecommunications and aviation sectors, privatisation of large state monopolies including Turk Telekom, building independent regulatory authorities (IRAs), ... etc., are among some of the important changes of this new institutional era. The implicit logic of all this so-called structural reforms is to create and enhance the market-based economy and the associated rationalisation of public management in line with it.

Actually, at first look, a new understanding and a new consensus on new rules of game depending on market mechanism seemed to have emerged in Turkey. After the introduction of these reforms, macroeconomic stability has substantially improved after 2001. A new social class has also been rising in Turkey who was supporting this new order of things [Pamuk, (2007), p.21; Altug et al., (2008), p.421]. In this framework, the role of state has changed from direct intervention to market to a kind of intervention by less burdensome methods. The positive state as a planner, direct producer of goods and services and the employer of last resort becomes the regulatory state. The regulatory state is giving more emphasis on the use of authority, rules and standard-setting rather than public ownership, public subsidies and direct provision of public goods [Jordana and Levi-Faur, (2004), p.8].

Although there are various meanings of regulation depending on different countries and time, for our concern, regulation is a specific form of governance involving a set of authoritative rules accompanied by an administrative agency in order to monitor and to enforce compliance [Jordana and Levi-Faur, (2004), p.3-4]. This administrative agency is different from traditional bureaucratic structures. IRAs are bodies which regulate, which posses some public authority and which are not hierarchically subordinate to elected politicians [Thatcher and Stone Sweet, (2002), p.2]. In other words, this agency model is distinguished by the combination of expertise and independence from traditional bureaucratic model [Majone, (1997), p.19]. The independence is the central focus of researchers since independence of the regulatory authority is a solution to politicians' time-inconsistent preferences [Gilardi, (2005), p.142].

IRAs are new and foreign for Turkish administrative tradition. Nevertheless, they have started to play an important role in the Turkish economy. They are creator of new rules and regulations via creating secondary legislations, setting industry standards and by discretionary decisions on disputes. The aim of this paper is to assess formal independence of IRAs in Turkey and in particular to expose effects of recent enormous legal amendments made in second half of 2011 on IRAs' independence. By Law No. 6223, government has got an authority for six months to make decree laws on determination of structure of public administrations in 2011. Equipped with this power, government has made fundamental changes in Turkish public administration structure. Actually, those amendments affect many diverse public administrations directly or indirectly that had some independence or autonomy from central government including Istanbul Stock Exchange and the Turkish Academy of Sciences. However, our focus on this paper is limited with IRAs. The essay will provide valuable knowledge on Turkey's experience of IRAs. 
The organisation of the paper is as follows: After this introduction, a short discussion on independence will be conducted. This is followed in Section 3 by providing a brief introduction of IRAs in Turkey. In Section 4, the method and the results are discussed. Finally, last section includes a brief summary and conclusions.

\section{Independence and independent regulatory authority}

There has been rapid adoption of liberalisation, privatisation and re-regulation by IRAs by both developed and developing countries since late 1980s. This trend sparks usage of term of regulatory state among some researchers and policy makers. According to Majone (1997, pp.12-13), the main function of emerging regulatory state is correcting market failures rather than redistribution and macroeconomic stabilisation. The instrument to achieve its goals is rule making rather than taxing and spending. The characteristic organisations are parliamentary committees, IRAs, commissions and tribunals.

IRAs are vital organisations in this setting. According to Majone (1997, p.17), for a regulatory state, administrative demands of rule making are different such that those demands are best met by flexible, highly specialised organisations enjoying considerable autonomy in decision making that are independent regulatory agencies. The advantages of IRAs are expertise and providing credible policy commitments. Traditional bureaucracies are inefficient to deal with the problems occurred at a utility sector after privatisation for instance since they are too generalist. Furthermore, according to Majone (1997, p.18) “... politicians have few incentives to develop policies whose success, if at all, will come after the next election". The problem is sourced from lack of commitment by elected government to deal with policies requiring continuity in long term, while there is a regular election cycle that is the main concern. Delegating policy making powers to independent administrations is a solution to this problem. This argument may make sense for Turkey since 1923 the average term of office for a government is less than 1.5 years [Durakoğlu, (2011), p.5580]. ${ }^{1}$ Another argument in favour of delegation is to avoid political uncertainty problem. Indeed, a government may fear replacement at next election. Then, it may try to endure its preferred policy at certain area beyond its term by delegation [Gilardi, (2005), p.140]. In other words, by creating an IRA in its current term, it may try to constrain policy options of the next government at future. In addition, other frequently used arguments in favour delegation are blame-shifting, efficiency, transparency and flexibility.

The meaning of independence should also be clarified. First of all, according to regulator capture argument regulated firms may try to affect the decisions of IRAs in favour of their interests. Therefore, IRAs potentially may be affected not only by politicians but regulated firms as well. In fact, there may be other interest groups such as civil society groups [Hanretty and Koop, (2012), p.199]. In this study independence implies insulation from political influence. Secondly, there are different definitions of independence (Verhoest et al., 2004). According to Hanretty and Koop (2012, p.199), formal independence from politics is the degree of independence from politics inherent in those legal instruments which constitute and govern the agency. Gilardi (2002, p.880) describes formal independence of regulators from elected politicians with five dimensions, namely the agency head status, the management board members' status, the 
general frame of the relationships with the government and the parliament, financial and organisational autonomy and the extent of delegated regulatory competencies. Actual independence or de facto independence refers the effective independence of agencies as they manage day-to-day regulatory actions [Maggetti, (2007), p.272]. Finally, while formal independence is more important to study delegation to IRAs since it reflects intentions of political decision makers to delegate their powers regarding providing credibility to regulatory policies, actual independence is more important to study the consequences of creating IRAs on the regulated sectors [Maggetti, (2007), p.272]. Since paper's interest is to reveal the effect of recent legal amendments regarding status of IRAs in Turkey, the notion of formal independence described by Gilardi $(2002, p .880)$ is adopted.

\section{IRAs in Turkey}

Turkey has experienced important institutional transformation during the last decades. Actually, the significant changes in institutional settings have started in 1980s as a neoclassical response of crisis of previous import-substitution industrialisation regime [Senses, (1991), pp.221-222]. Turkey has abandoned the import substitution policies after a serious balance of payment crisis. Foreign trade regime has been liberalised and export oriented development strategy has been adopted. The main goal has been to create a market-based economy integrated with the world markets. The most dramatic changes have occurred at financial sector such as major banking reform legislation with new accounting and reporting standards, a deposit insurance schema and capital requirements, putting private banks under supervision of Central Bank via reserve requirements, capital ratios, and loan provisions; and the creation of an interbank market [Senses, (1991), p.221]. However, this first wave of institutional change is not adequate to support stability and growth in the long term.

More visible institutional change in Turkey has been occurred at last decade and establishment of IRAs is an important part of this transformation. The sources of this institutional change were a mixture of domestic and external factors that emerged before, during and in the immediate aftermath of the 2000-2001 economic crises. ${ }^{2}$ In fact, Turkey was faced with four major crises since the early 1990s; in 1994, 1999, 2001 and finally the global crisis of 2008-2009. The GDP has shrunk 5.4\% in 1994, 2.6\% in 1999 , $9.2 \%$ in 2001 , and $4.7 \%$ in $2008-2009 .{ }^{3}$ Hence, Turkey has signed a new Stand-by Agreement with the IMF and EU has recognised Turkey as a candidate country ${ }^{4}$ during the 57th government period.

In the process of EU membership, it is required from Turkey that there should be a functioning market economy and the capacity to cope with competitive pressures and market forces in the EU. In particular, they mean prohibition of direct public sector financing by the central bank, prohibition of privileged access of the public sector to financial institutions, independence of the central bank and liberalisation of capital movements. Therefore, the adoption of EUs Acquis Communautaire means a substantial structural transformation hand in hand with significant institutional transformation for Turkey. For instance, the Competition Authority (CA) was established in $1997^{5}$ as part of the Custom Union agreement with the European Union (EU). 
The stabilisation program has included a reorganisation of the social security system, agriculture, and banking sector as well as the privatisation of some public enterprises in order to reverse the unsustainable public debt dynamic (The Undersecretariat of Treasury of R.T., 1999; 4th article). The targets have been to reduce both inflation and real interest rate. In this framework, privatisation has been seen as an immediate source of substantial financial resource to reduce the public debt (The Undersecretariat of Treasury of R.T., 1999; 23th and 48th articles). However, there is also an expectation of economic efficiency improvement via privatisation. The telecommunications sector and electricity sector are selected sectors for privatisation and liberalisation. Furthermore, since these sectors have high fixed and sunk costs, some regulatory intervention is necessary to prevent private monopolies. With this stabilisation program and promises, substantial amount of credit has been supplied to Turkey by the IMF.

On the other hand, the political commitment to so called structural reforms has not been very much. After the liquidity squeeze in financial markets and the dispute between the Prime Minister Bülent Ecevit and the President Ahmet Necded Sezer, an economic crisis has occurred and the stabilisation program has collapsed. A new Stand-by Agreement was signed with IMF in 2002 in order to be implemented between 2002 and 2004 period. The Letter of Intent dated 2002 is clearer and consistent though it has been built on previous reforms inherited in the Letter of Intent dated 1999. The suggested policies are tight fiscal policy, inflation targeting under a floating exchange rate regime, completion of banking sector restructuring and enhancing the role of the private sector in the economy by accelerating privatisation especially (The Undersecretariat of Treasury of R.T., 2002; 9th article).

As a result, massive amendments in existing legal texts or enactment of new laws such as the Law on Intellectual Property Rights are made. Those changes have defined new rules for economic actors. The Central Bank's independence from the political authorities that is perceived as a vital guarantee for prevention of irresponsible monetary policies, liberalisation of electricity, gas, telecommunications and aviation sectors, privatisation plans of large state monopolies at those utilities sector including Turk Telekom, building IRAs, ... etc., are among some of the important characteristics of the transformation.

The reforms after 2001 crisis have aims of both avoiding future economic crises and achieving sustainable high growth rates. After the introduction of second wave of institutional change, macroeconomic stability has substantially improved. ${ }^{6}$ Öniş (2004, pp.12-13) claims that the reasons of successful growth performance at following several years after 2001 crisis are tight fiscal policy as well as structural reforms like restructuring of banking sectors in particular. Altug et al. (2008, p.415) give the credit for strong recovery after 2001 crisis to improvement in institutional environment thanks to the IMF and the EU as well as the most private sector friendly Government in Turkey's history that is the Justice and Development Party (AKP).

Today, there are mainly nine IRAs in Turkey:

- Capital Markets Board of Turkey (CMB).

- Radio and Television Supreme Council (RTSC).

- Competition Authority (CA).

- Banking Regulation and Supervision Agency (BRSA). 
- Information and Communication Technologies Authority (ICTA).

- Energy Market Regulatory Authority (EMRA).

- The Turkish Sugar Authority (SA).

- $\quad$ Tobacco and Alcohol Market Regulatory Authority (TAMRA).

- $\quad$ Public Procurement Agency (PPA).

The CMB of Turkey was established in 1982 by Capital Market Law No. 2499 in order to provide effective regulatory framework for developing capital markets. The task of the $\mathrm{CMB}$ is to establish capital markets and provision of regulatory framework in order to protect the rights of investors. The CMB has seven members who are appointed for six years by the Council of Ministers. ${ }^{7}$ It might be called an early example of IRAs.

When the CMB was established in 1982, the status of it regarding the Turkish administration system was an entity 'related' to the Ministry of Finance. Therefore, since many of its actions were dependent on approval of Ministry of Finance, it could not be said that it was a completely independent authority similar to one in Europe or USA. However, with two amendments of Capital Market Law No. 2499 that were enacted in 1992 and 1999 it has become more independent. ${ }^{8}$ Current status is that it is 'affiliated' with a Deputy Prime Ministry.

The RTSC was established in 1994 to regulate broadcasting market following liberalisation. Prior to 1994 , there had been a state monopoly in radio and television broadcasting in Turkey. The responsibilities of RTSC are to allocate frequencies of wireless spectrum to the broadcasting companies, to regulate the competition in the market and to control the content broadcasted. ${ }^{9}$ RTSC has nine members who were appointed six years by the Grand National Assembly of Turkey.

Turkish Competition Law No. 4054 was enacted in 1994 and the $C A$ was established to enforce Turkish Competition Law. The goal of the CA is to facilitate and to protect competition in markets. While the CA was established in 1994, the members of Competition Board were not appointed until 1997. The Competition Board has seven members who are appointed for six years by the Council of Ministers. ${ }^{10}$ According to Turkish Competition Law, the CA has an administrative and financial autonomy, it is 'related' with the Ministry of Customs and Trade, and it is independent in fulfilling its duties. In fact it is explicitly stated in the Law that "No organ, authority and person may give commands and orders to influence the final decision of the Authority". 11

Within the efforts of comprehensive restructuring of the Turkish banking industry, Law of Banking No. 4389 was enacted in 1999. The BRSA was established in 2000 to regulate the industry. However, provision of independence has been achieved with some legal amendments in the Law of Banking. The BRSA has administrative and financial autonomy. ${ }^{12}$ Actually, Turkey has carried out the promises on a standby agreement in 1999 with the IMF. Interestingly, however, in 2003 government forced the head of BRSA to resign. Besides, a new law ${ }^{13}$ enacted in 2001 that amended Law of Banking contained a stipulation terminating the terms of the existing members of BRSA. Currently, the BRSA has seven members who are appointed for six years by the Council of Ministers. The Chairman and Vice Chairman are appointed from the Board members by the Council of Ministers directly. 
The establishment of the ICTA to regulate the Turkish telecommunication industry followed an official undertaking by the Turkish Government to privatise its state-owned monopoly telecommunications operator and liberalise its telecommunications market as part of a credit agreement with the WB in 2000. Previously, both the Ministry of Transportation and Türk Telekomünikasyon A.Ș. were responsible to regulate the industry. Law No. 4502 dated January 27, 2000, ${ }^{14}$ which boosted the structural reform from monopoly towards a liberalised telecommunications industry, set forth the date of liberalisation for fixed line telephone services as 31.12.2003. ${ }^{15}$ That Law, amending the Wireless Law $^{16}$ and Telegraph and Telephone Law, ${ }^{17}$ which were the two basic telecommunications laws in Turkey, constituted the baseline not only for opening telecommunications infrastructure and services to competition, but also for regulating the industry, e.g., by means of interconnection and roaming obligations, pricing rules, dispute resolution processes. To fulfil these duties, a regulatory body called 'Telecommunications Authority' was established in 2000. The Law No. 5809 or Electronic Communications Law $^{18}$ amended the Wireless Law in 2008 so that 'Telecommunications Authority' term has changed to 'ICTA'.

According to Electronic Communications Law, ICTA has administrative and financial autonomy. According to the article 67 of Electronic Communications Law, "The Authority is independent in fulfilling its duties. No organ, authority and person may give commands and orders to influence the final decision of the Authority". The Information and Communication Technologies Board has seven members who are appointed by the Council of Ministers.

Similar to the telecommunications sector, the IMF has conditioned the liberalisation of electricity and natural gas sectors (The Undersecretariat of Treasury of R.T., 1999; 48th article). The obligation naturally consists of the establishment of IRAs for respective markets. Although the Electricity Market Regulation Authority was created by the Electricity Market Law No. 4628 in February 2001, a joint regulator, namely The EMRA, was established for both electricity and gas markets by the Law No. 4646. The Board of EMRA has nine members who are appointed by the Council of Ministers.

The PPA was established by the Public Procurement Law No. 4734 in $2002 .{ }^{19}$ The main duty of the PPA is to design and to develop the principles and procedure for public procurement process. Public Procurement Board has nine members who were appointed for four years by the Council of Ministers. ${ }^{20}$ It also enjoys financial and administrative autonomy as well as independence.

The public procurement policy of EU is effective to adopt such legislation as well as establishment of the PPA. A public procurement policy should be non-discriminatory and transparent regarding EU legislation in order to prevent rent seeking behaviours and corruption. Although EU does not condition establishment of the PPA as an independent regulatory authority, Turkey has promised to the IMF to establish the PPA.

The Turkish $S A$ was established and started its operations in 2001 by the Sugar Law No. $4634 .{ }^{21}$ The aim of the Sugar Law is to satisfy domestic sugar demand by domestic production and when necessary to regulate the sugar industry for exportation. Clearly, this task is unusual. In fact, the existence of the SA is a peculiar to Turkey. Actually, it has planned as temporary and the conditional sunset clause of the Sugar Law seek to end in 2004 for it. The government has decided to close the SA in 2004 and the Sugar Board in 2006. However, a worker union, namely Şeker İş, has appealed this decision and the Constitutional Court has decided that the conditional sunset clause of Sugar Law was against the Constitution. ${ }^{22}$ 
The Sugar Board has seven members who were appointed for five years by the Council of Ministers. As a distinctive feature with respect to other independent regulatory institutions, the members of sugar Board for SA are permitted to continue with their existing jobs. In fact, most of the members appointed for the Board were state employees in other state offices.

The TAMRA was established in 2002 by the Law No. 4733 in order to regulate the tobacco, tobacco products, and alcoholic beverages markets. ${ }^{23}$ TAMRA has also responsible for developing and implementing policies to reduce consumption of tobacco and alcoholic beverages. The Tobacco Board has seven members who were appointed for five years by the Council of Ministers. Similar to sugar case, the members of Tobacco Board are permitted to continue with existing jobs.

\section{The independence of IRAs in Turkey}

In mid-2011, significant legislative change has occurred regarding administrative structure of Turkish state. In fact, Law No. $6223^{24}$ gave an authority to the government for six months period to make decree laws on determination of structure of public administrations. Then the government has made fundamental changes in Turkish public administration structure. Some of them are outlined at below that are important from our perspective:

- Eight ministries have been closed and 11 new ministries have been set up.

- By Decree Law No. 649, IRAs can be inspected by their relevant and/or affiliated Ministries.

- By Decree Law No. 655, some responsibilities of some IRAs have been retransferred to the relevant Ministries.

- By Decree Law No. 661, some amendments are made in Law No. 4734 such that vice presidents, head legal adviser and department heads at PPA have been relieved from duty. Moreover, three vice presidents of PPA are appointed by the Ministry directly while before the amendment the Board was appointing the vice presidents.

- By Decree Law No. 666, compensations of experts at IRAs are fixed to level of compensations of experts at Prime Ministry and compensations of Board members are fixed to level of compensations of deputy undersecretary of affiliated Ministry.

To understand how those changes affect formal independence of Turkish IRAs, a formal independence index approach will be employed. Actually, there are attempts to quantify independence of IRAs by using index method (Gilardi, 2002; Gutiérrez, 2003; Edwards and Waverman, 2006; Montoya and Trillas, 2007; Waverman and Koutroumpis, 2011). All indexes are constructed based on some indicators regarding some aspects of independence of the agency. For Turkish IRAs, Zenginobuz (2008) also conducted a study on formal independence by using Gilardi's index approach. Zenginobuz (2008, p.500) concluded that most of Turkish IRAs were created with considerable operational and financial independence. 
In this paper, Gilardi's approach is adopted. Gilardi (2002) constructed a single independence index. It is consisted of five components: the agency head status, the management board members' status, the general frame of the relationships with the government and the parliament, financial and organisational autonomy and the extent of delegated regulatory competencies. There are indicators associated with those components such that each indicator has a value between 0 and 1.0 shows the lowest level of independence while 1 shows the highest level of independence. For each component, mean of indicators is calculated. Then mean of all values calculated for each component gives the value of overall independent index.

In this framework, each indicator and each component has an equal weight. Gilardi (2002, p.880) admits that choosing weights is inevitably arbitrary process and he preferred an equal weighting. Not surprisingly, this is not the only criticism. According to Hanretty and Koop (2012, pp.199-205) existing indices of formal independence suffer from several flaws. First criticism is that most indices conflate breadth of powers with independence. In other words, if an agency can do more things, then its index number will be higher. However, an agency has limited powers but it can act more independently. Second criticism is that depending on the language of legislation the result may be higher or lower. In other words, if some important points do not explicitly addressed by legislation then index number may be lower. Third criticism is that the ordering of response categories may not be right. Finally, for items with multiple responses the assumption of equal spaces such as $1,0.5$ and 0 may not be true. As a result, they also propose to drop several items from indices such as the appointment method. Although those criticisms have some merits, the particular goal of the paper is to compare formal independence levels of Turkish IRAs relative to distinct point in different times to asses change in the formal independence status in time. Hence, index method is not very accurate but sufficient approach.

For seven IRAs in Turkey, this index is calculated at both before the legal amendments of 2011 and after it. Indeed, telephone interviews with senior staff or executives have been conducted to collect data for some indicators. Therefore, there is a chance for some error. The results can be seen in Table 1. The overall formal independence index numbers calculated for all of the IRAs are declining after legal amendments in mid-2011. The highest decline is seen at the PPAs index score. Indeed, for the PPA, overall index score is 0.79 before the legal amendments. That decreases to 0.64 . In other words, after legal amendments have been realised, the score of overall formal independence index for the PPA has declined $18.9 \%$. Most of this reduction is sourced from decline in financial and organisational autonomy part. The change in other IRAs' scores seems very moderate relative to magnitude of this change. For instance, the next steeper decline is seen for the BRSA as $5 \%$ or in absolute terms overall index score is decreasing from 0.77 to 0.73 . Actually, for other IRAs most of the reduction at overall index score is sourced from decline at budget autonomy indicator.

By Decree Law No. 666, compensations of experts at IRAs are fixed to level of compensations of experts at Prime Ministry and compensations of Board members are fixed to level of compensations of deputy undersecretary of affiliated Ministry. In other words, IRAs cannot determine compensation level for their employees. In practice, this amendment means degradation of compensations of employees of IRAs. An immediate negative consequence of this amendment is that compensation level for new recruits are declining significantly. In time, IRAs may not be able to attract talented young people for expert career. 
Table 1 Formal independence of Turkish IRAs before and after legal amendments in 2011

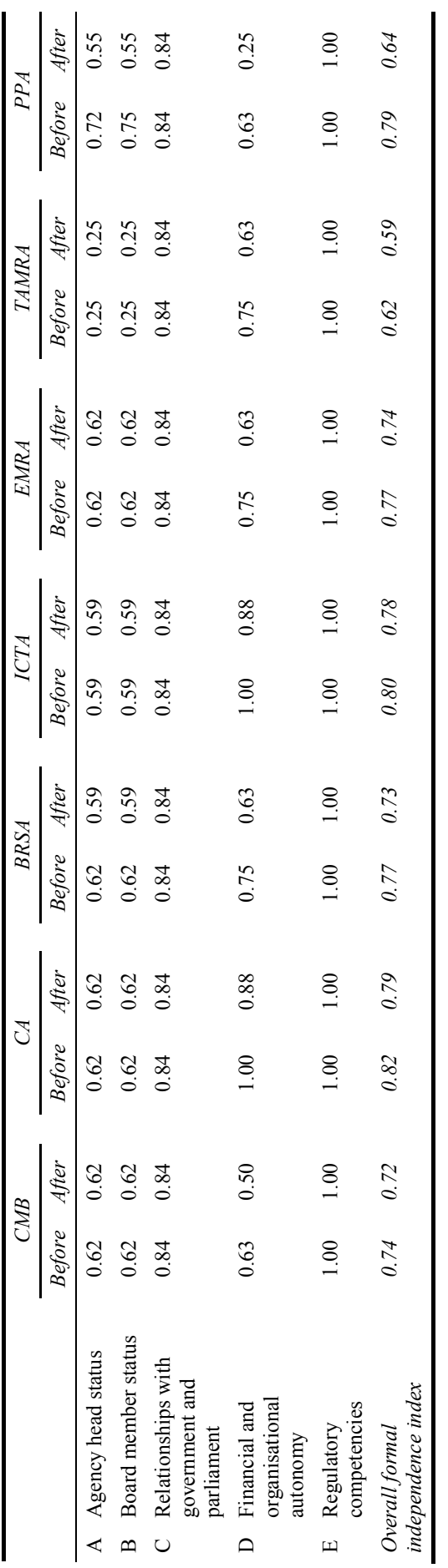


It should be noted that even before those amendments and despite the financial autonomy written at founding laws, some expending decisions of IRAs are constrained. For instance, with Circular No. 2003/39 published by the Prime Ministry some austerity measures are defined for including IRAs. Those measures constrain expenses of IRAs that would be made in both domestic and foreign territories. To illustrate, any business trip to a foreign country must be confirmed by the relevant or affiliated Ministry. Although this austerity measure may make sense after 2001 economic crisis, this regulation is still in force.

From Table 1, it can be seen that scores of two components of overall independence index namely agency head status and board member status for all IRAs are relatively low. In Turkey, most members of the Board are often nominated by the relevant Ministry or other Ministries and existing member can be nominated again. The appointments to the Boards of IRAs are made by the Council of Ministers. At Anglo-Saxon tradition of regulation, founding a commission is a way to diminish the partisan effect on decisions. Usually, some members are chosen from different interest groups such as consumer associations and/or firm associations representing industry. Moreover, only a small number of members are chosen at one time, because it is aimed to diminish the possible dominance of any political group in power. In addition to these, once the appointment is realised, they are not forced to resign except under unusual circumstances. Before these massive legal changes, there is one case such that all members of the Board of BRSA have been relieved from duty by changing law in 2003. The second example has been created by amending Law No. 4734 by Decree Law No. 661 such that vice presidents, head legal adviser and department heads at PPA have been relieved from duty. Furthermore, the Ministry has gained power to make direct appointments for vice president positions at there. Indeed, this is another reason why the PPAs financial and organisational autonomy index declines.

There are some other amendments which are problematic in the context of independence debate. One of them is that decisions and actions of IRAs have become to be inspected by Ministers by Decree Law No. 649. While actions and decisions of IRAs could be challenged only via courts, it is important how this new inspection authority is put on practice. Moreover, this new authority seems to be contradictory with articles at founding Laws that provide administrative and financial independence to IRAs. Another problematic issue is that new amendments will probably create more grey area on division of labour between IRAs and their relevant Ministries. For instance, some authorities of the ICTA have been transferred to the new found Ministry of Transportation, Shipping and Communications by Decree Law No. $655 .{ }^{25}$ These authorities include determining price floors and caps (if it is required) in order to encourage competition in communications services market. ${ }^{26}$ Nevertheless, Communications Law No. 5809 has already given a similar authority to national regulatory authority, namely ICTA. Besides, Ministries have still considerable power on the utility companies. This may create conflict of interests between the Ministry and regulatory administration. At present, according to Cetin and Oguz (2007, pp.1767-1768) existence of divergent views between Ministry and related independent regulatory authority is frequent in Turkey.

Before those amendments, the emerging institutional environment was still far from perfect. There were vague areas, which create uncertainties for IRAs and, so they reduce benefits expected from those organisations. Burnham (2007, p.206) argues that there was a need for a clear re-affirmation of overall policy at that highest level of government. 
Legal ambiguities between regulatory agencies might create power struggles and inefficiency. For instance, the CA makes ex-post regulations, while sector specific regulatory authority, ICTA, is specialised at ex-ante regulations. From an integrated perspective, they have complementarily relationship in function. However, existing laws give both administrations a duty to enforce competition ex-post. This ill-definition of administrative boundaries has sparked conflicting views and disputes among them [Ardıyok and Oğuz, (2010), pp.6-9; Atiyas and Doğan, (2007), p.504]. Burnham (2007, p.206) suggests enhancing greater cooperation and information sharing between the two major regulatory agencies.

There may be several factors explaining what reasons might be behind the decline in formal independence. First of all, decisive external factors supporting institutional transformation after 2001 economic crisis have weakened. Stand-by arrangements with IMF have been completed in 2008. There is no any demand for IMFs help from the government after that date. Improved investment and general macroeconomic climate means that credits from the World Bank are less important now than volatile previous years in Turkey. Besides, privatisation efforts have already advanced. Actually, the era after 2000 is distinct from earlier period in the sense that there is dramatic increase in privatisation efforts especially in utilities sectors in Turkey. The Turkish Government has obtained more than $\$ 32$ billion revenue from privatisation over the period 2004 and 2010. This amount exceeds the total amount obtained from previous privatisations by a big margin. ${ }^{27}$ Hence, need to prove policy commitment for privatisation and liberalisation is not vital at the end of the decade once it was vital issue. In addition, EU membership process has lost its momentum thanks to the opposition of conservative Sarkozy presidency in France and Merkel Government in Germany. In fact, this strong opposition as well as the global financial crisis' negative effects on EU has significantly weakened incentives to adopt the Acquis Communautaire.

Second factor may be related with political uncertainty. One possible argument in favour delegation of power to an independent regulatory authority by government is fear of replacement at election cycle. However, the current government, ${ }^{28}$ elected three times successively during the last decade, is probably one of the most powerful and enduring Government in Turkey's political history. Based on consecutive electoral success with strong majority as well as better economic environment, the government may seek to centralise more power at its hands. These intentions have been announced repeatedly by various members of the government during the last decade. For instance, at the TV speech Deputy Prime Minister, responsible for economic management, Ali Babacan underlies the IMF and the WB conditionality when the IRAs have been founded and then he suggests that "This approach was the result of logic of that bankrupted Turkey at that time but since then contemporary Turkey has changed too much. Policy making must be done by political will" (The Undersecretariat of Treasury of R.T., 2011). Actually, he said that there were legal amendments at planning phase such that after the general election of 2011 some of authority of those institutions would return to the government. As a matter of fact, the government has passed the Law No, 6223 right after the election. To justify these actions, Ali Babacan suggests that those IRAs who done failed actions in the past point the government for the failure. Some decisions which requires 'political will' must be made by government with having full responsibility. Therefore, some authorities requiring 'political will' and others not requiring 'political will' should be separated. 
Finally, there seems to be resistance to IRAs among political class in Turkey. In other words, the approach that is delegation of power to IRAs does not belong practices of political elites in Turkey. Even the Turkish Constitution promotes a strict indivisibility of administration. That issue triggered a debate among certain circles especially among jurists that under these circumstances founding a really independent regulatory authority similar to those at Anglo-Saxon countries is not possible legally. The opponents of this view underline other provisions of the Turkish Constitution in support of founding IRAs. Perhaps, the best example exposing the resistance is the liberalisation and privatisation issue. Atiyas (2009, pp.6-7) informs us that the law, which would enable privatisation of Turk Telekom in 1990s, has been cancelled by the Constitutional Court because there was no regulatory framework to be implemented after privatisation. Clearly, privatisation of network monopoly without proper regulation leads to negative welfare consequences in the long run. However, the government was focused on only the amount of revenue generated by privatisation. Atiyas (2009, pp.19-22) provides more dramatic example to how the current government' motives are for privatisation from electricity sector: A law passed in 2005 permits the vertical integration between electricity distribution and retail sales firms. His comment on this change is that "...was indicating either that the development of a competitive industry was not a main concern or that the Ministry of Energy did not really understand the necessary conditions for such a development take place". According to Erdogdu (2009, p.1493) "The whole privatization process appears to aim providing additional revenues to Treasury without paying attention to the crucial underlying economic logic". The hidden motive is to make more attractive for potential investors to maximise privatisation revenue by granting monopoly rents. ${ }^{29}$ In short, government sees privatisation as panacea and it is only interested in privatisation revenue obtained in the short term. In fact, according to Durakoğlu (2011, p.5579), there is an ongoing tension between the government and EMRA on regulatory policies in Turkey.

\section{Conclusions}

Establishment of IRAs is an important part of institutional transformation in Turkey. They are relatively new and their independence from political power is attracted debate among public time to time. The current government has made fundamental changes in Turkish public administration structure including IRAs in 2011. A formal independence index approach used by Gilardi (2002) is employed to consider effects of those legal amendments on formal independence of IRAs. According to results, formal independence scores calculated after legal amendments in 2011 are lower than formal independence scores calculated before those amendments. The highest decline is seen at the PPAs index score. The decrease in financial and organisational autonomy is main source of decline. Possible motives behind this trend may be weakening effects of external actors like the IMF and the EU, strong electoral power of existing government and resurfacing old habits of Turkish political elites.

\section{Acknowledgements}

The views and interpretations expressed here belong to the authors and cannot be attributed to the ICTA (Bilgi Teknolojileri ve İletişim Kurumu) in Turkey or its affiliated organisations or any other individual acting on behalf of these organisations. 


\section{References}

Akdemir, E., Başçı, E. and Locksley, G. (2005) 'Turkish telecommunications sector: a comparative analysis', in Hoekman, B. and Togan, S. (Eds.): Turkey: Economic Reform and Accession to the European Union, World Bank and the Centre of Economic Policy Research, Washington, USA.

Altug, S., Filiztekin, A. and Pamuk, Ş. (2008) 'Sources of long-term economic growth for Turkey, 1880-2005', European Review of Economic History, Vol. 12, No. 3, pp.393-430.

Ardiyok, Ş. and Oğuz, F. (2010) 'Competition law and regulation in the Turkish telecommunications industry: friends or foes?', Telecommunications Policy, Vol. 34, No. 4, pp.233-243.

Atiyas, İ. (2009) 'Recent privatization experience of Turkey - a reappraisal' [online] http://myweb.sabanciuniv.edu/izak/files/2009/12/privatization_reappraisal5.pdf (accessed 05/03/2013).

Atiyas, İ. and Doğan, P. (2007) 'When good intentions are not enough: sequential entry and competition in the Turkish mobile industry', Telecommunications Policy, Vol. 31, Nos. 8-9, pp.502-523.

Burnham, J.B. (2007) 'Telecommunications policy in Turkey: dismantling barriers to growth', Telecommunications Policy, Vol. 31, Nos. 3-4, pp.197-208.

Capital Markets Board of Turkey [online] http://www.cmb.gov.tr/indexcont.aspx? action $=$ showpage \&menuid $=0$ \&pid $=0 \&$ submenuheader $=-1($ accessed 05/03/2013).

Cetin, T. and Oguz, F. (2007) 'The reform in the Turkish natural gas market: a critical evaluation', Energy Policy, Vol. 35, No. 7, pp.3856-3867.

Competition Authority [online] http://www.rekabet.gov.tr/index.php?Sayfa=sayfahtml\&Id=437 (accessed 27/11/2011).

Durakoğlu, S.M. (2011) 'Political institutions of electricity regulation: the case of Turkey', Energy Policy, Vol. 39, No. 9, pp.5578-5587.

Edwards, G. and Waverman, L. (2006) 'The effects of public ownership and regulatory independence on regulatory outcomes', Journal of Regulatory Economics, Vol. 29, No. 1, pp.23-67.

Energy Market Regulatory Authority [online] http://www.epdk.gov.tr/english/default.asp (accessed 27/11/2011).

Erdogdu, E. (2009) 'Some thoughts on the Turkish electricity distribution industry', Renewable and Sustainable Energy Review, Vol. 13, Nos. 6-7, pp.1485-1494.

Gilardi, F. (2002) 'Policy credibility and delegation to independent regulatory agencies: a comparative empirical analysis', Journal of European Public Policy, Vol. 9, No. 6, pp.873-893.

Gilardi, F. (2005) 'The formal independence of regulators: a comparison of 17 countries and 7 sectors', Swiss Political Science Review, Vol. 11, No. 4, pp.139-167.

Gutiérrez, L.H. (2003) 'Regulatory governance in the Latin American telecommunications sector', Utilities Policy, Vol. 11, No. 4, pp.225-240.

Hanretty, C. and Koop, C. (2012) 'Measuring the formal independence of regulatory agencies', Journal of European Public Policy, Vol. 19, No. 2, pp.198-216.

Information and Communications Technologies Authority [online] http://www.tk.gov.tr/Eng/abo_boa/history.html (accessed 27/11/2011).

Jordana, J. and Levi-Faur, D. (2004) 'The politics of regulation in the age of governance', in Jordana, J. and Levi-Faur (Eds.): The Politics of Regulation: Institutions and Regulatory Reforms for the Age of Governance, The CRC Series on competition, regulation and development, Edward Elgar, USA. 
Kulalı, İ. and Bilir H. (2010) Bilgi ve İletişim (Telekomünikasyon) Sektöründeki Gelişmeler ve Eğilimler: Global Finansal Kriz Sürecinde Yeniden Yapılanma ve Çözüm Arayışları, TOBB.

Maggetti, M. (2007) 'De facto independence after delegation: a fuzzy-set analysis', Regulation \& Governance, Vol. 1, No. 4, pp.271-294.

Majone, G. (1997) From the Positive to the Regulatory State: Causes and Consequences of Changes in the Mode of Governance, Estudio/Working paper 1997/93 [online] http://www.march.es/ceacs/publicaciones/working/archivos/1996_93.pdf (accessed 05/03/2013).

Montoya, M.A. and Trillas, F. (2007) 'The measurement of the independence of telecommunications regulatory agencies in Latin America and the Caribbean', Utilities Policy, Vol. 15, No. 3, pp.182-190.

Öniş, Z. (2004) The Political Economy of Turkey's Justice and Development Party, Revised Draft [online] http://papers.ssrn.com/sol3/papers.cfm?abstract_id=659463 (accessed 05/03/2013).

Pamuk, Ş. (2007) Economic Change in Twentieth Century Turkey: Is the Glass More than Half Full?, Working paper No. 41, The American University of Paris [online] http://www.aup.fr/pdf/WPSeries/AUP_wp41-Pamuk.pdf (accessed 05/03/2013).

Privatization Administration of Republic of Turkey (2010) 2010 Annual Report [online] http://www.oib.gov.tr (accessed 05/03/2013).

Senses, F. (1991) 'Turkey's stabilization and structural adjustment program in retrospect and prospect', The Developing Economies, Vol. 29, No. 3, pp.210-234 [online] http://www.ide.go.jp/English/Publish/Periodicals/De/pdf/91_03_02.pdf (accessed 05/03/2013).

Thatcher, M. and Stone Sweet, A. (2002) 'Theory and practice of delegation to non-Majoritarian institutions', West European Politics, Vol. 25, No. 1, pp.1-22.

The Undersecretariat of Treasury of R.T. (1999) Stand by Arrangement Letter of Intent, 9 December [online]

http://www.treasury.gov.tr/irj/portal/anonymous?NavigationTarget=navurl://87d806706d285d 6a6a7aa571a6bfbd41\&LightDTNKnobID=-1605662990 (accessed 27/11/2011).

The Undersecretariat of Treasury of R.T. (2002) New Stand by Arrangement 2002-2004 Letter of Intent, 18 January [online]

http://www.treasury.gov.tr/irj/portal/anonymous?NavigationTarget=navurl://87d806706d285d 6a6a7aa571a6bfbd41\&LightDTNKnobID=-1605662990 (accessed 27/11/2011).

The Undersecretariat of Treasury of R.T. (2011) 'Devlet Bakani ve Başbakan Yardimcisi Sn. Ali Babacan', CNN Türk Televizyonu Ankara Temsilcisi Sn. Hande Firat'a Canli Yayinda Verdiği Özel Röportaj, 6 May [online]

http://www.hazine.gov.tr/irj/go/km/docs/documents/Devlet\%20Bakanligi/R\%c3\% (accessed 27/11/2011).

Verhoest, K., Peters, B.G., Bouckaert, G. and Verschuere, B. (2004) 'The study of organizational autonomy: a conceptual review', Public Administration and Development, Vol. 24, No. 2, pp.101-118.

Waverman, L. and Koutroumpis, P. (2011) 'Benchmarking telecoms regulation - the telecommunications regulatory governance index (TRGI)', Telecommunications Policy, Vol. 35, No. 5, pp.450-468.

Zenginobuz, E.Ü. (2008) 'On regulatory agencies in Turkey and their independence', Turkish Studies, Vol. 9, No. 3, pp.475-505. 


\section{Notes}

1 The Justice and Development Party (AKP) is a significant outlier, which is at office since 2002.

2 Although 2008-2009 global financial crisis affects Turkish economy negatively, sources of crisis are international in nature [Kulalı and Bilir, (2010), pp.7-11].

3 The rates of change in GDP for first three crises are calculated by using GDP values at 1987 prices. The rate of change in GDP for the last crisis is calculated by using GDP values at 1998 prices. All data are obtained from TUIKK website (http://www.tuik.gov.tr).

4 Turkey was recognised as an EU candidate country by EU Helsinki Council as of December 1999 summit.

5 The founding Law has passed in 1994.

6 Although it is true that Turkish GDP has contracted 4.7\% in 2009 due to the global financial crisis, the growth rate of GDP in 2010 reached $9 \%$.

7 http://www.spk.gov.tr/indexcont.aspx? action $=$ showpage $\&$ menuid $=0 \&$ pid $=0 \&$ submenuheader $=-1$.

8 In particular, one should understand independence as administrative and financial independence. However, independence issue has been explicitly stated in laws for other IRAs.

9 http://www.rtuk.org.tr/sayfalar/IcerikGoster.aspx? icerik id=80775e05-caec-4a48-bac5-39fd6375da3b.

$10 \mathrm{http}: / /$ www.rekabet.gov.tr/index.php?Sayfa=sayfaicerik\&icId=165.

11 Article 20, http://www.rekabet.gov.tr/index.php?Sayfa=sayfaicerik\&icId=165.

12 Article 82 of the Law of Banking No. 5411.

13 The Law No. 4672 of May 2001 that is published at Official Gazette No. 24416 on May 29, 2001, http://rega.basbakanlik.gov.tr/main.aspx? home=http://rega.basbakanlik.gov.tr/eskiler/2001/05/20010529.htm\&main=http://rega.basbak anlik.gov.tr/eskiler/2001/05/20010529.htm.

14 The Law No. 4502, http://www.tk.gov.tr/eng/duzenmaineng2.html.

15 In 1998 the Turkish Government had committed itself, in accordance with the World Trade Organization guidelines, to liberalise its fixed-line telephone network and services no later than the end of 2004. Law No. 4502 has shifted the liberalisation timetable to the end of 2003 to accelerate the process [Akdemir et al., (2005), p.152].

16 In 1998 the Turkish Government had committed itself, in accordance with the World Trade Organization guidelines, to liberalise its fixed-line telephone network and services no later than the end of 2004. Law No. 4502 has shifted the liberalisation timetable to the end of 2003 to accelerate the process [Akdemir et al., (2005), p.152].

17 The Telegraph and Telephone Law No. 406, http://www.tk.gov.tr/eng/pdf/ 406.pdf.

18 http://www.tk.gov.tr/eng/duzenmaineng2.html.

19 The Law No. 4734 http://rega.basbakanlik.gov.tr/main.aspx? home=http://rega.basbakanlik.gov.tr/eskiler/2002/01/20020122.htm\&main=http://rega.basbak anlik.gov.tr/eskiler/2002/01/20020122.htm.

20 The Decree Law No. 661. Before that law, Public Procurement Board had ten members who had been appointed for five years.

21 It is published at Official Gazette No. 24378 on April 19, 2001, http://rega.basbakanlik.gov.tr/main.aspx?home=http://rega.basbakanlik.gov.tr/eskiler/2001/04/ 20010419.htm\&main=http://rega.basbakanlik.gov.tr/eskiler/2001/04/20010419.htm.

22 The Constitutional Court Decision No. 2008/102 on May 2, 2008. http://www.anayasa.gov.tr/index.php? $1=$ manage_karar\&ref $=$ show\&action $=$ karar\&id $=2634 \&$ content $=$. 
23 The Law No. 4733, http://rega.basbakanlik.gov.tr/main.aspx? home=http://rega.basbakanlik.gov.tr/eskiler/2002/01/20020109.htm\&main=http://rega.basbak anlik.gov.tr/eskiler/2002/01/20020109.htm.

24 It is published at Official Gazette No. 27923 on May 2011.

25 It is published at reiterated Official Gazette No. 28102 on November 2011.

26 By Decree Law No. 655, it also seems that authorities on:

a enforcing technical standards at communications sector

$b$ regulating rights of way

c managing international relations about communications have been transferred from the ICTA to the Ministry of Transportation, Shipping and Communications.

27 According to the Republic of Turkey Prime Ministry Privatization Administration of Republic of Turkey (2010), total privatisation revenue over the period 1986 and 2010 is equal to 40.3 billion USD.

28 The Justice and Development Party (AKP).

29 A similar case has occurred during privatisation of Turk Telekom in 2005. The government has tried to privatise Turk Telekom as a whole. However, the CA has conditioned to the government to separate cable network infrastructure from Turk Telekom. At the same time, the CA has required to set up distinct firm for internet access business at retail level. The existing cable network has been a real infrastructure alternative for Turk Telekom's classical network. On the other hand, it has not been privatised yet. 